\title{
Kajian Kualitas Air dan Indeks Pencemaran Perairan Laut di Teluk Manado Ditinjau Dari Parameter Fisika-Kimia Air Laut
}

\section{Water Quality and Sea Pollution Index in Manado Bay the View Physical-Chemical Paramaters Sea}

\author{
Simon I. Patty ${ }^{1)}$, Marenda Pandu Rizki ${ }^{*}$, Husen Rifai" dan Nebuchadnezzar Akbar ${ }^{2}$ \\ ${ }^{1 *}$ Loka Konservasi Bita Laut Bitung-LIPI \\ ${ }^{2}$ Program Studi Ilmu Kelautan, FPIK, Universitas Khairun, Ternate \\ E-mail: pattysimon@ymail.com
}

\begin{abstract}
ABSTRAK
Penelitian ini telah dilaksanakan pada dua musim yaitu musim barat dan musim peralihan-I untuk mengetahui kualitas air laut dan indeks pencemaran di Teluk Manado. Pengukuran suhu, salinitas, kecerahan, $\mathrm{pH}$ dan oksigen terlarut dilakukan secara in situ (langsung di lapangan) sedangkan kekeruhan, fosfat dan nitrat dianalisa di labaratorium WLN-Manado. Semua metode analisis berdasarkan pada buku Standards Methods for The Examination of Water and Wastewater (APHA, AWWA, WEF, 2005). Hasil perhitungan indeks pencemaran menunjukkan Teluk Manado masih dalam kondisi baik hingga tercemar ringan. Variasi nilai suhu, salinitas, kecerahan dan kekeruhan air laut masih dalam kondisi relatif normal untuk kategori perairan pantai. Derajat keasaman $(\mathrm{pH})$, oksigen terlarut (DO), fosfat dan nitrat masih dalam batas aman kesuburan suatu perairan dan masih baik untuk kehidupan dan perkembangan biota laut.
\end{abstract}

Kata kunci: Kualitas air, karakteristik fisika-kimia, Teluk Manado

\section{ABSTRACT}

This research has been carried out in two seasons (western and transitional-I seasons) in order to find out the quality of sea water and pollution index in the Bay of Manado. Measurements of temperature, salinity, regulation, $\mathrm{pH}$ and dissolved oxygen were conducted in situ, whilst turbidity, phosphate and nitrate were analyzed in the WLN-Manado laboratory. All analysis methods were based on the Book of Standard Methods for Water and Wastewater Examination (APHA, AWWA, WEF, 2005). Pollution index calculation results showed that Manado Bay was in the range of good until lightly polluted condition. Variations in temperature, salinity, resolution and turbidity of sea water were still in relatively normal conditions for the coastal transportation category. The degree of acidity $(\mathrm{pH})$, dissolved oxygen (DO), phosphate and nitrate were still in the range of good condition and thus safe for the life and development of marine creatures.

Keywords: Water quality, physical-chemical characteristics, Manado Bay 


\section{Pendahuluan}

Teluk Manado merupakan perairan pantai dan estuari yang sangat penting di bidang perikanan, terletak diantara $1^{\circ} 27^{\prime}-1^{\circ} 34^{\prime}$ LU dan $124^{\circ} 45^{\prime}-124^{\circ} 51^{\prime}$ BT. Secara geografis, perairan Teluk Manado masuk dalam kawasan Taman Nasional Bunaken, berhadapan langsung dengan Samudera Pasifik, yakni Laut Sulawesi yang memiliki profil topografi yang curam dan dalam. Bagian utara perairan Teluk Manado terdapat lima buah pulau diantaranya Bunaken, Siladen, Manado Tua, Mantehage dan Nain. Perairan ini memiliki kekayaan ekologis dengan tingkat keragaman dan kelimpahan biota laut yang cukup tinggi. Disamping itu, potensi terumbu karang berserta keanekaragaman biotanya menyebabkan berkembangnya kegiatan wisata bahari. Tidak mengherankan bila perairan Teluk Manado juga dijadikan sebagai destinasi wisata bahari bagi masyarakat Manado bahkan wisatawan mancanegara.

Wilayah perairan Teluk Manado akhir-akhir ini semakin meningkat perannya, sejalan dengan pembangunan di Kota Manado, baik dilihat dari fungsi ekonomi maupun ekologis. Teluk Manado menempatkannya sebagai salah satu perairan yang memeberikan kontribusi cukup signifikan untuk kegiatan pariwisata, transportasi, industri dan kegiatan lainnya. Selain itu, Teluk Manado juga mempunyai fungsi ekologis dimana perairan ini merupakan daerah fishing ground bagi nelayan setempat. Sebagai peraian pantai, kondisinya sangat dipengaruhi oleh lingkungan disekitarnya, aktivitas pelabuhan yang tidak terkontrol, buangan bahan bakar dari armada transportasi laut, sampah dari penduduk sekitar, limbah-limbah dari berbagai industri serta bahan pencemar lainnya yang masuk ke Teluk Manado dapat mengakibatkan perubahan terhadap kualitas air laut di perairan ini.

Setiap bahan pencemar yang masuk ke badan air di perairan Teluk Manado berpotensi menyebabkan penurunan kualitas perairan yang akan mengurangi fungsi biologis dan ekologis terhadap ekosistem didalamnya. Oleh karena itu pengelolaan kualitas dan pengendalian pencemaran air laut perlu dilakukan untuk menjaga agar potensi wilayah ini tetap terjaga dan memberi manfaat bagi masyarakat. Penelitian ini bertujuan untuk mengetahui kualitas air laut dan menentukan status pencemaran di Teluk Manado dari beberapa parameter fisika-kimia air laut.

\section{Metode Penelitian}

\subsection{Waktu dan tempat penelitian}

Penelitian dilaksanakan di Teluk Manado pada bulan Januari-Pebruari (musim barat/MB) dan April-Mei (Musim peralihan-I/MP-I) tahun 2017. Parameter lingkungan yang diukur diantaranya adalah suhu, salinitas, kecerahan, kekeruhan, $\mathrm{pH}$, oksigen terlarut, fosfat dan nitrat. Penentuan posisi masing-masing stasion penelitian dilakukan dengan menggunakan Garmin Handportable GPS Map 60 CSx (Gambar 1).

\subsection{Pengambilan data perairan}

Sampel air laut diambil dengan menggunakan tabung nansen pada lapisan permukaan sebanyak 11 stasion. Pengukuran suhu, salinitas, kecerahan, $\mathrm{pH}$ dan oksigen terlarut dilakukan secara in situ (langsung di lapangan), berturut-turut diukur dengan menggunakan thermometer GMK-910T, Atago hand refractometer, cakram (sechi disk), pH meter AZ 8682 dan oksigen terlarut ditentukan dengan metode elektrokimia menggunakan alat DO meter AZ 8563. Analisa kekeruhan, fosfat dan nitrat dilakukan secara ex situ (di labaratorium WLNManado), dengan menggunakan metode turbidimetri untuk kekeruhan dan spektrofotometri untuk kadar fosfat dan nitrat. Kekeruhan ditentukan dengan menggunakan alat turbidimeter, nilainya dinyatakan dalam NTU; sedangkan kadar fosfat dan nitrat dengan menggunakan alat spektrofotometer 'UV-Vis', nilainya dinyatakan dalam $\mathrm{mg} / \mathrm{l}$. Semua metode analisis 
berdasarkan pada buku Standards Methods for The Examination of Water and Wastewater (APHA, AWWA, WEF, 2005).

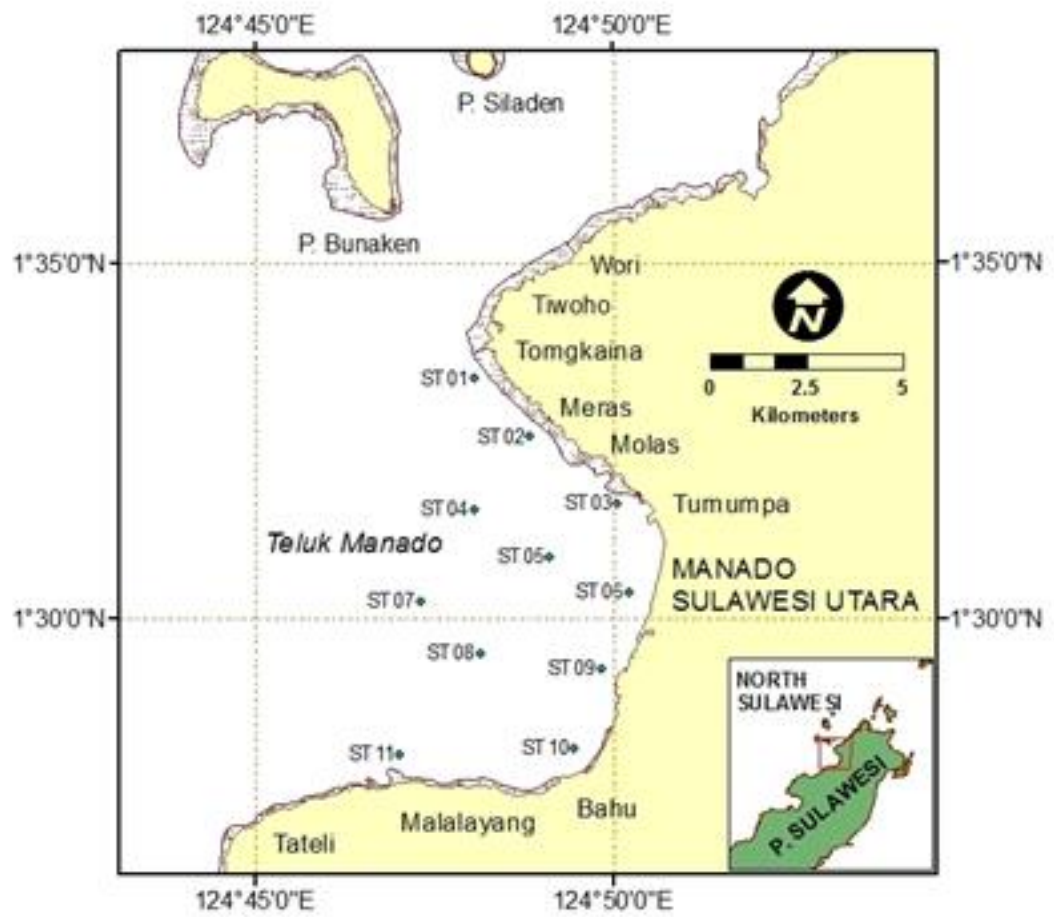

Gambar 1. Peta Stasiun Penelitian Oseanografi di Perairan Laut Teluk Manado.

Data hasil pengukuran lapangan dan hasil analisa laboratorium dihitung Indeks Pencemaran (PI) selanjutnya dievaluasi secara deskriptif berdasarkan kriteria indeks pencemaran dengan membandingkan baku mutu kualitas air laut untuk biota laut menurut Keputusan Menteri Negara Lingkungan Hidup Nomor 51 Tahun 2004. Penentuan status pencemaran ditentukan dengan menggunakan Indeks Pencemaran menurut Nemerow and Sumitomo (1970) dalam Keputusan Menteri Negara Lingkungan Hidup Nomor 115 Tahun 2003 tentang Pedoman Penentuan Status Mutu Air sebagai berikut:

Dimana :

$$
P I_{j}=\sqrt{\frac{\left(C_{i} / L_{i j}\right)_{M}^{2}+\left(C_{i} / L_{i j}\right)_{R}^{2}}{2}}
$$

$\mathrm{C}_{\mathrm{i}}=$ Kosentrasi parameter kualitas air hasil survei

$\mathrm{L}_{\mathrm{ij}}=$ Kosentrasi parameter kualitas air dalam baku mutu peruntukan (j)

$\mathrm{PI}_{\mathrm{j}}=$ Indeks pencemaran bagi peruntukan (j)

$\left(\mathrm{C}_{\mathrm{i}} / \mathrm{L}_{\mathrm{ij}}\right)_{\mathrm{M}}=$ Nilai $\mathrm{C}_{\mathrm{i}} / \mathrm{L}_{\mathrm{ij}}$ Maksimum

$\left(\mathrm{C}_{\mathrm{i}} / \mathrm{L}_{\mathrm{ij}}\right)_{\mathrm{R}}=$ Nilai $\mathrm{C}_{\mathrm{i}} / \mathrm{L}_{\mathrm{ij}}$ Rata-rata

Kriteria status mutu air laut berdasarkan nilai Indeks Pencemaran sebagai berikut :

1. $0 \leq \mathrm{PIj} \leq 1,0$ : memenuhi baku mutu (kondisi baik)

2. $1,0 \leq \mathrm{PIj} \leq 5,0$ : tercemar ringan

3. $5,0 \leq \mathrm{PIj} \leq 10$ : tercemar sedang

4. $\mathrm{PI}_{\mathrm{j}} \geq 10 \quad$ : tercemar berat 


\section{Hasil dan Pembahasan}

\subsection{Pengukuran Kualitas Air Laut dan Indeks Pencemaran}

Hasil pengukuran kualitas air laut dan indeks pencemaran di Teluk Manado pada musim barat/MB dan musim peralihan-I/MP-I dan hasil perhitungan indeks pencemaran (Tabel 1 dan 2).

Tabel 1. Kisaran dan rerata beberapa parameter kualitas air laut di Teluk Manado.

\begin{tabular}{l|c|c|c|c|c}
\hline \multirow{2}{*}{ Parameter } & Baku & \multicolumn{2}{|c|}{ Musim Barat } & \multicolumn{2}{c}{ Musim Peralihan-I } \\
\cline { 3 - 6 } & mutu *) & Kisaran & Rerata \pm Std & Kisaran & Rerata \pm Std \\
\hline Fisik & & & & & \\
Suhu $\left({ }^{\circ} \mathrm{C}\right)$ & $28-30$ & $27,3-29,2$ & $28,1 \pm 0,61$ & $27,9-29,5$ & $28,8 \pm 0,44$ \\
Salinitas $(\%$ \%o $)$ & $33-34$ & $29,0-33,0$ & $31,5 \pm 1,46$ & $31,5-34,0$ & $32,8 \pm 0,68$ \\
Kecerahan $(\mathrm{m})$ & $>5$ & $1,5-10,5$ & $6,4 \pm 2,74$ & $6,0-15,0$ & $10,0 \pm 2,79$ \\
Turb. $(\mathrm{NTU})$ & $<5$ & $1,42-4,52$ & $2,57 \pm 0,94$ & $0,45-1,35$ & $0,80 \pm 0,25$ \\
Kimia & & & & & \\
pH & $7-8,5$ & $7,27-8,02$ & $7,68 \pm 0,27$ & $7,52-8,07$ & $7,87 \pm 0,19$ \\
DO $(\mathrm{mg} / \mathrm{l})$ & $>5$ & $5,56-6,81$ & $6,29 \pm 0,45$ & $6,03-7,23$ & $6,68 \pm 0,38$ \\
Fosfat $(\mathrm{mg} / \mathrm{l})$ & 0,015 & $0,0039-0,0214$ & $0,0088 \pm 0,0056$ & $0,0024-0,0099$ & $0,0044 \pm 0,0021$ \\
Nitrat $(\mathrm{mg} / \mathrm{l})$ & 0,008 & $0,0043-0,0223$ & $0,0091 \pm 0,0048 *$ & $0,0023-0,0128$ & $0,0052 \pm 0,0028$ \\
\hline
\end{tabular}

*) Baku mutu air laut untuk biota laut (Kepmen LH No 51 Tahun 2004).

Tabel 2. Nilai indeks pencemaran air laut di Teluk Manado.

\begin{tabular}{|c|c|c|c|c|c|c|c|c|}
\hline \multirow[b]{2}{*}{ St. } & \multicolumn{4}{|c|}{ Musim Barat } & \multicolumn{4}{|c|}{ Musim Peralihan-I } \\
\hline & $\begin{array}{c}\mathrm{Ci} / \mathrm{Lij} \\
\mathrm{Max}\end{array}$ & $\begin{array}{l}\mathrm{Ci} / \mathrm{Lij} \\
\text { Rerata }\end{array}$ & $\mathrm{PIj}$ & Status & $\begin{array}{c}\mathrm{Ci} / \mathrm{Lij} \\
\mathrm{Max}\end{array}$ & $\begin{array}{l}\mathrm{Ci} / \mathrm{Lij} \\
\text { Rerata }\end{array}$ & PIj & Status \\
\hline 1 & 0.99 & 0.00 & 0.70 & Kondisi baik & 0.56 & -0.22 & 0.43 & Kondisi baik \\
\hline 2 & 1.16 & -0.02 & 0.82 & Kondisi baik & 0.48 & -0.10 & 0.34 & Kondisi baik \\
\hline 3 & 1.63 & 0.28 & 1.17 & Tercemar ringan & 0.55 & -0.04 & 0.39 & Kondisi baik \\
\hline 4 & 0.55 & -0.14 & 0.40 & Kondisi baik & 0.74 & -0.18 & 0.54 & Kondisi baik \\
\hline 5 & 1.42 & 0.14 & 1.01 & Tercemar ringan & 0.90 & -0.08 & 0.64 & Kondisi baik \\
\hline 6 & 3.23 & 0.65 & 2.33 & Tercemar ringan & 2.02 & 0.28 & 1.44 & Tercemar ringan \\
\hline 7 & 0.56 & -0.12 & 0.41 & Kondisi baik & 0.67 & -0.21 & 0.49 & Kondisi baik \\
\hline 8 & 1.11 & -0.04 & 0.78 & Kondisi baik & 0.56 & -0.13 & 0.41 & Kondisi baik \\
\hline 9 & 1.23 & -0.01 & 0.87 & Kondisi baik & 0.59 & -0.10 & 0.42 & Kondisi baik \\
\hline 10 & 1.05 & 0.01 & 0.75 & Kondisi baik & 0.70 & -0.10 & 0.50 & Kondisi baik \\
\hline 11 & 0.89 & 0.00 & 0.63 & Kondisi baik & 0.53 & -0.06 & 0.38 & Kondisi baik \\
\hline
\end{tabular}

\subsubsection{Suhu Perairan}

Suhu sangat berpengaruh terhadap kehidupan dan pertumbuhan biota perairan, apabila suhu air mencapai kisaran $35-40{ }^{\circ} \mathrm{C}$ merupakan suhu kritis bagi kehidupan organisme yang dapat menyebabkan kematian. Suhu air laut yang diperleh pada musim barat berkisar antara $27,3-29,2{ }^{\circ} \mathrm{C}$ dengan rata-rata $28,1 \pm 0,61^{\circ} \mathrm{C}$ dan musim peralihan-I berkisar antara $27,9-29,5$ ${ }^{\circ} \mathrm{C}$ dengan rata-rata $28,8 \pm 0,44{ }^{\circ} \mathrm{C}$. Nilai suhu ini sesuai dengan kisaran suhu air di perairan laut umumnya, dimana nilai suhu di lapisan permukaan laut yang normal berkisar antara 20,0-30,0 ${ }^{\circ} \mathrm{C}$ (Nybakken, 1988). Menurut Nontji (2002) suhu air laut permukaan di perairan Indonesia pada umumnya berkisar antara $28-31{ }^{\circ} \mathrm{C}$. Sejauh ini, kisaran suhu yang teramati masih dalam batas kisaran optimal suhu air laut yaitu 28-32 ${ }^{\circ} \mathrm{C}$ dan sesuai untuk kehidupan 
biota laut (Kepmen LH No 51 Tahun 2004). Suhu air dengan nilai tertinggi mendekat ke darat, sebaliknya ke arah laut suhu airnya makin rendah (Gambar 2). Kondisi ini menunjukkan bahwa pergerakan massa air tawar dari aliran sungai-sungai yang dengan mudah masuk ke perairan dekat pantai. Gerakan massa air ini yang dapat menimbulkan panas, akibat terjadi gesekan antara molekul air, sehingga suhu air laut di perairan dekat pantai lebih hangat dibanding dengan massa air di perairan lepas pantai (Tarigan dan Edward, 2000).

Suhu air dengan kisaran yang berbeda di kedua musim ini diduga karena faktor perbedaan waktu pada saat pengamatan. Seperti yang dijelaskan oleh Effendi (2003) bahwa suhu perairan dipengaruhi oleh musim, lintang (latitude), ketinggian dari permukaan laut (altitude), waktu dalam hari, sirkulasi udara, penutupan awan dan aliran serta kedalaman badan air. Musim barat di perairan Teluk Manado ditandai dengan tiupan angin barat yang sangat kuat disertai gelombang dan arus menyebabkan penetrasi cahaya matahari ke permukaan laut tidak efektif sehingga suhu air permukaan rendah. Sebaliknya pada musim peralihan-I penetrasi cahaya cukup efektif karena cuacanya baik dan langit relatif cerah. Hal ini sejalan dengen pernyataan Officer (1976) bahwa kondisi suhu air di suatu perairan di pengaruhi terutama oleh kondisi atmosfir, cuaca dan intensitas matahari yang masuk ke laut. Selain itu suhu air juga dipengaruhi oleh faktor geografis dan dinamika arus (Pond \& Pickard, 1978).
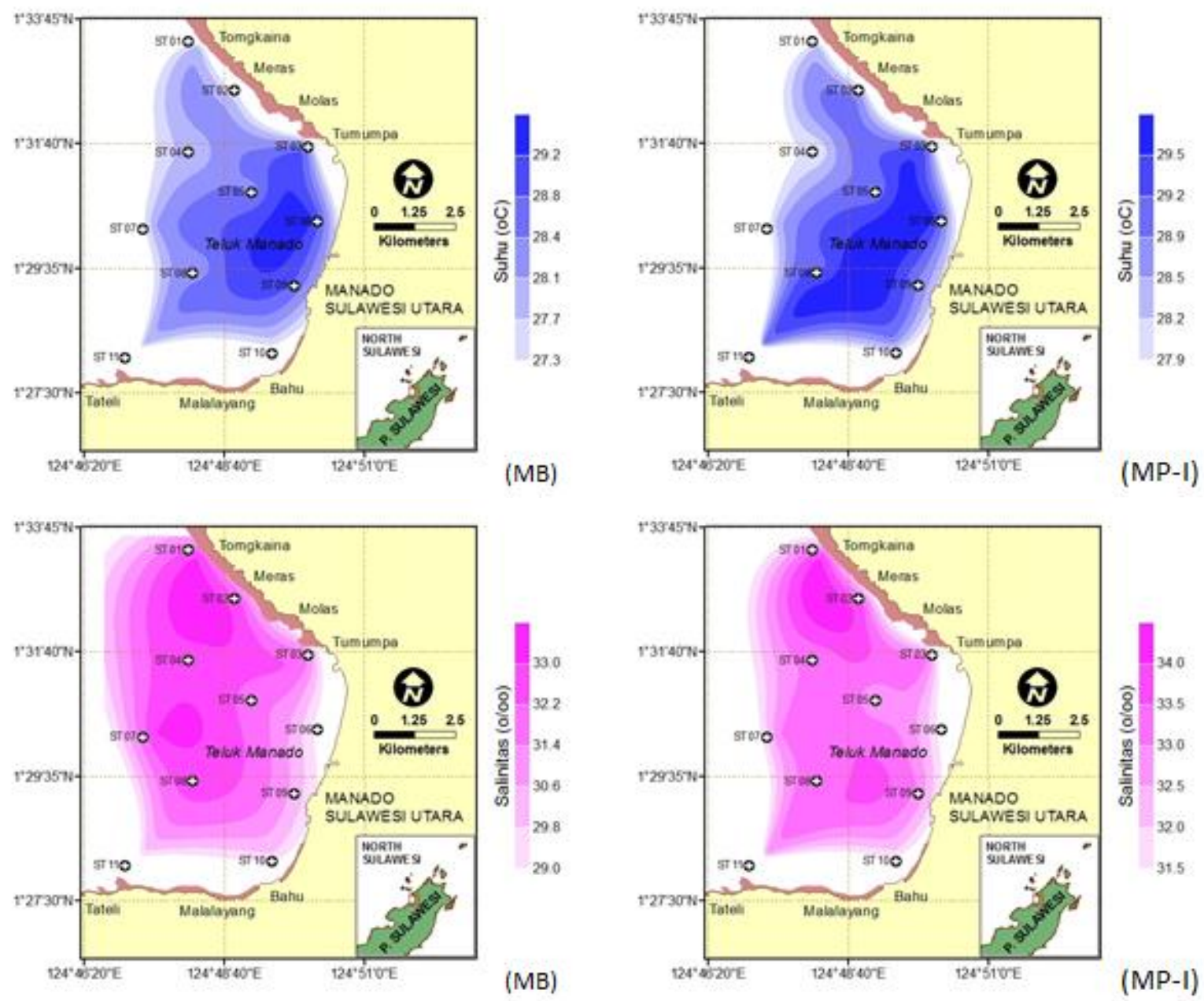

Gambar 2. Sebaran suhu dan salinitas pada musim barat (MB) dan musim peralihan-I (MP-I) di perairan Teluk Manado. 


\subsubsection{Salinitas}

Nilai salinitas ini erat kaitannya dengan musim, dimana pada musim barat salinitas berkisar antara 29,0-33,0 \% dengan rata-rata $31,5 \pm 1,46 \%$, sedangkan pada musim

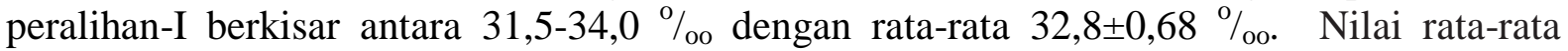
salinitas dari kedua musim ini lebih rendah dibandingkan yang didapatkan Kalangi dkk., 2013 di perairan Teluk Manado yaitu 33,19-34,67\% \% Selanjutnya Hadikusumah dan Sugiarto (2001) mengemukakan bahwa salinitas permukaan sampai pada kedalaman 10 meter di perairan Sulawesi dan sekitarnya berkisar antara 33,7-33,8\%. Rendahnya salinitas ini kemungkinan disebabkan oleh adanya suplay air tawar melalui aliran sungai yang bermuara diperairan laut. Faktor yang mempengaruhi hingga berbedanya nilai salinitas di kedua musim adalah cuaca dan angin. Banjarnahor (2000) mengemukakan bahwa perbedaan nilai salinitas disebabkan oleh terjadinya pengacauan (mixing) akibat gelombang laut ataupun gerakan massa air yang ditimbulkan oleh tiupan angin). Pada musim barat dikenal tiupan angin barat yang sangat kuat disertai gelombang dan arus menyebabkan tingkat penguapan (evaporasi) terhambat sehingga diduga dapat memperkecil nilai salinitas. Selain itu musim barat di wilayah ini merupakan musim hujan, dengan curah hujan yang tinggi menyebabkan salinitas air permukaannya rendah. Gambaran salinitas di perairan ini menginformasikan bahwa fluktuasi salinitas diduga dipengaruhi oleh beberapa faktor, diantaranya oleh pola sirkulasi air, penguapan (evaporasi), curah hujan (presipitasi) dan adanya aliran sungai/run off (Bowden, 1980; Nontji, 2002).

Salinitas menunjukkan nilai tertinggi penyebarannya ke arah laut dan ke arah darat nilai salinitasnya makin rendah (Gambar 2). Kondisi ini menunjukkan bahwa sebaran salinitas di laut dipengaruhi oleh berbagai faktor, seperti pola sirkulasi air, penguapan, curah hujan dan aliran sungai (Nontji, 2002). Dari hasil pengukuran salinitas terlihat nilainya masih $<32,0 \%$, maka perairan masih dipengaruhi oleh pantai, diduga adanya pengaruh dari daratan seperti percampuran dengan air tawar yang terbawa aliran sungai. Nilai salinitas di perairan ini masih berada dalam batas-batas salinitas yang normal air pantai dan air campuran yaitu 32,0-34,0\% (K. Romimohtarto dan S. S. Thayib, 1982) dan sesuai dengan baku mutu air laut untuk biota laut (Kepmen LH No 51 Tahun 2004).

\subsubsection{Kecerahan}

Hasil pengukuran kecerahan air menunjukkan nilai tertinggi 6,0-15,0 meter dengan rata-rata 10,0 $\pm 2,79$ meter diperoleh pada musim peralihan-I dan terendah pada musim barat yaitu berkisar antara 1,5-10,5 meter dengan rata-rata 6,4 2,74 meter. Rendahnya kecerahan air di musim barat diduga disebabkan oleh adanya pengaruh hujan dan resuspensi sedimen akibat pola arus. Kondisi ini menunjukkan bahwa tingkat kecerahan air di perairan ini sangat tergantung pada musim dan sedimentasi yang berasal dari sungai masuk ke perairan laut. Tingkat kecerahan air terendah sebarannya menuju ke arah darat dan ke arah laut tingkat kecerahannya makin tinggi (Gambar 3). Kecerahan terendah $<5$ meter dijumpai (Stasiun 3, 5 dan 6) dan nilainya masih dibawah baku mutu air yaitu > 5 meter (Kepmen LH No 51 Tahun 2004). Kurangnya kecerahan air dikarenakan stasiun-stasiun tersebut dekat dengan aktivitas pelabuhan dan sungai yang banyak membawa sedimen, partikel terlarut, bahan organik dan anorganik masuk ke perairan laut yang menyebabkan air keruh. Kekeruhan air dapat menghambat penetrasi cahaya yang masuk ke perairan mengakibatkan nilai kecerahan air rendah. Sebagaimana yang diungkapkan oleh Mechta, 1989 bahwa kecerahan sangat dipengaruhi oleh intensitas penyinaran matahari, proses absorbsi dan kandungan materi suspensi. 

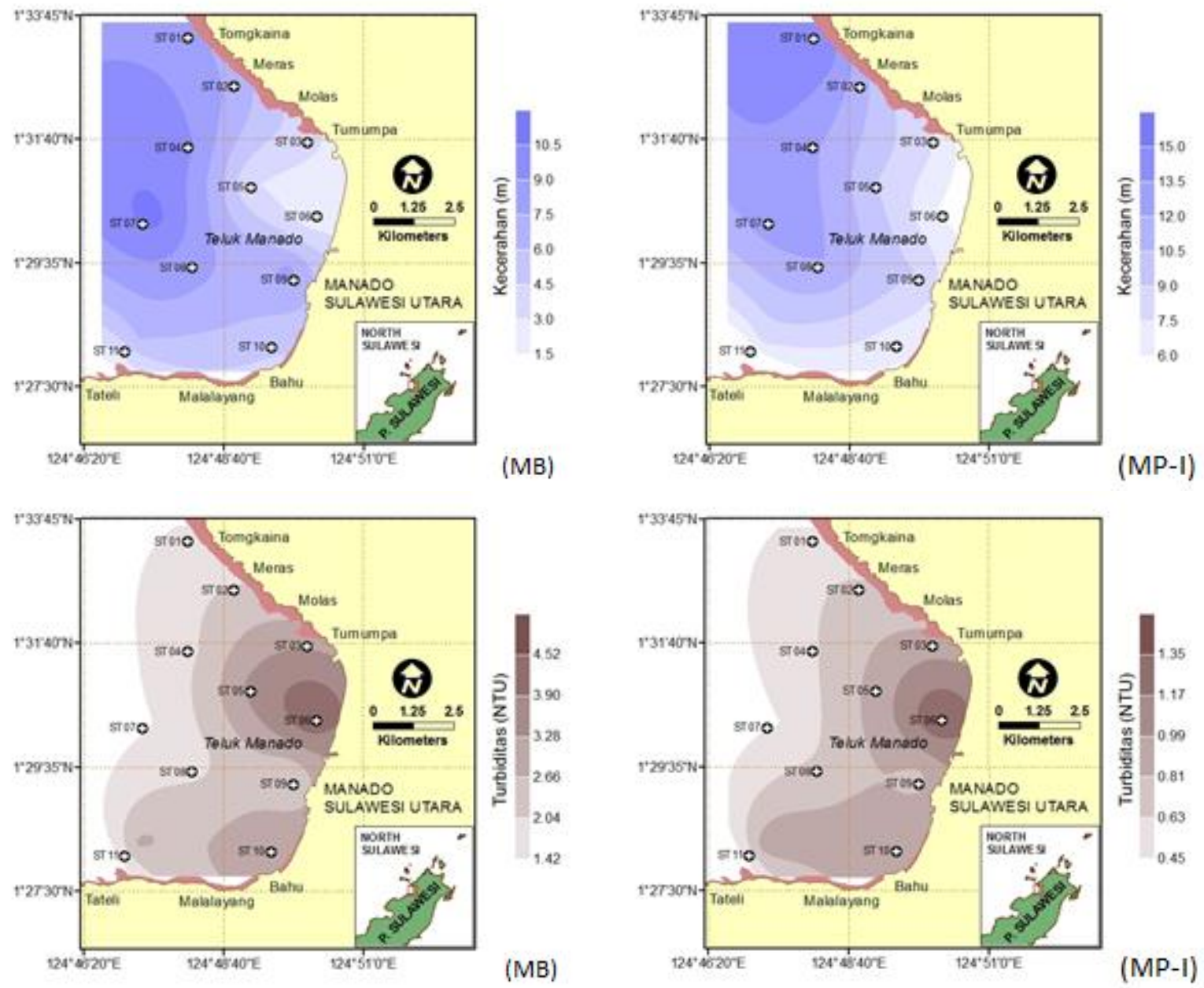

Gambar 3. Sebaran kecerahan dan kekeruhan air pada musim barat (MB) dan musim peralihan-I (MP-I) di perairan Teluk Manado.

\subsubsection{Kekeruhan}

Kekeruhan atau turbidity menggambarkan kurangnya kecerahan perairan akibat adanya bahan-bahan koloid dan tersuspensi seperti lumpur, bahan organik dan anorganik dan mikroorganisme perairan (Wilson, 2010). Kekeruhan air pada musim barat berkisar antara

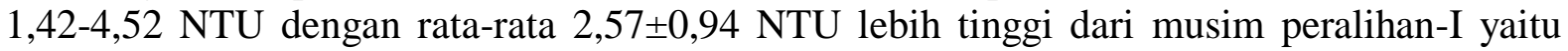

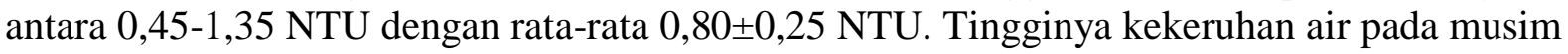
barat disebabkan faktor curah hujan yang tinggi dan run-off dari daratan lewat sungai-sungai serta turbulensi dari gelombang maupun arus yang kuat pada perairan. Curah hujan yang tinggi terjadi di musim barat mengakibatkan banyaknya substrat berupa lumpur, limbah rumah tangga dan sampah melalui aliran run-off dari daratan masuk ke perairan, serta kuatnya arus yang menyebabkan teraduknya substrat hingga air laut keruh. Kekeruhan air laut dengan nilai tertinggi mendomonasi perairan pantai dekat dengan muara sungai dan sebaliknya ke arah laut kekeruhan airnya makin rendah (Gambar 3). Kondisi ini menunjukkan bahwa tingkat kekeruhan tertinggi berada di daerah dekat pantai yang cenderung mendapatkan masukan dari daratan. Kecenderungan tingginya kekeruhan air laut di perairan ini ada kaitannya dengan tingkat kebersihan perairan terutama pada saat hujan, namun tidak melebihi baku mutu air laut untuk biota laut yaitu <5 NTU (Kepmen LH No 51 Tahun 2004). 


\subsubsection{Derajat keasaman (pH)}

Variasi nilai derajat keasaman $(\mathrm{pH})$ air laut dapat dijadikan sebagai salah satu indikator kualitas air laut. Suatu perairan laut yang baik biasanya bersifat basa dengan $\mathrm{pH}>7$. Nilai $\mathrm{pH}$ pada musim barat berkisar antara 7,27-8,02 dengan rata-rata 7,68 $\pm 0,27$ dan musim

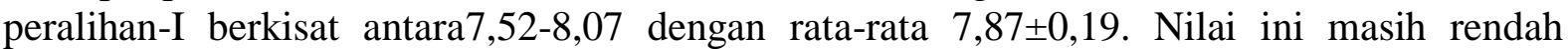
dibawah pH normal perairan, menurut Salm (1984), $\mathrm{pH}$ di suatu perairan yang normal berkisar antara 8,0-8,3. Rendahnya nilai $\mathrm{pH}$ diduga dipengaruhi oleh massa air dari beberapa muara sungai sungai, curah hujan maupun proses oksidasi yang dapat mengakibatkan rendahnya nilai $\mathrm{pH}$. Besarnya nilai $\mathrm{pH}$ air laut di perairan ini masih baik untuk kehidupan biota laut. Kepmen LH No 51 Tahun 2004 menetapkan nilai pH untuk biota laut berkisar antara 7,0-8,5; sedangkan Pescod dalam Susana (2005) memberikan batasan $\mathrm{pH}$ yang ideal bagi biota laut nilainya berkisar antara 6,5-8,5. Variasi nilai $\mathrm{pH}$ air laut di setiap stasiun relatif homogen, baik pada musim barat maupun musim peralihan-I (Gambar 4). Kondisi ini dikarenakan air laut memiliki pH relatif lebih stabil dan berada dalam kisaran yang sempit, biasanya dipengaruhi oleh kapasitas penyangga (buffer) yaitu adanya garam-garam karbonat dan bikarbonat yang dikandungnya (Nybakken, 1988).
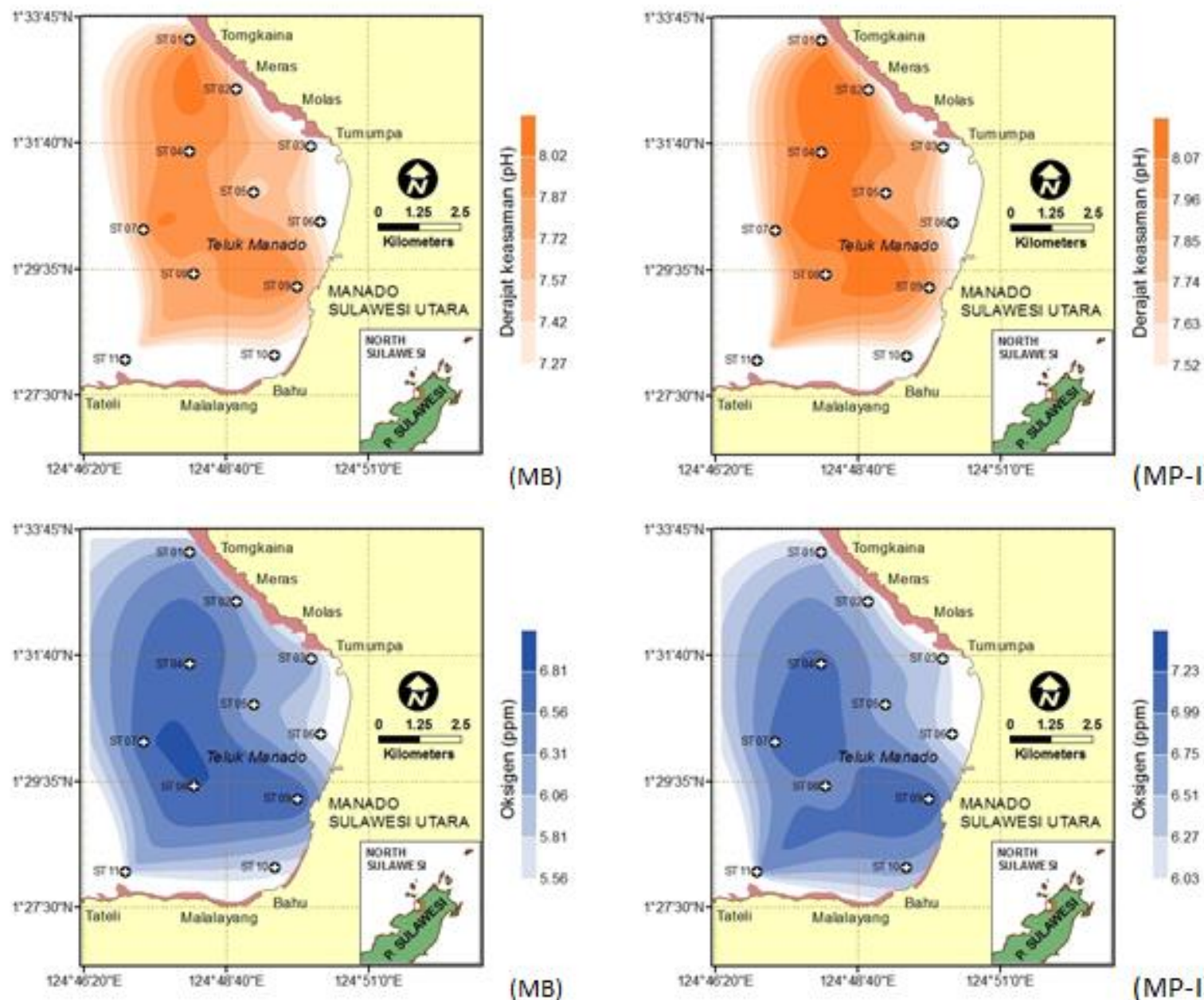

Gambar 4. Sebaran pH dan oksigen terlarut pada musim barat (MB) dan musim peralihan-I (MP-I) di perairan Teluk Manado. 


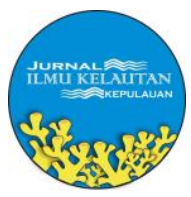

\subsubsection{Oksigen Terlarut (DO)}

Oksigen dalam air dimanfaatkan oleh organisme perairan untuk proses respirasi dan menguraikan zat organik menjadi anorganik oleh mikro organisme. Menurunnya kadar oksigen terlarut akan mengakibatkan berkurangnya aktivitas kehidupan dalam suatu perairan. Kadar oksigen terlarut pada musim barat berkisar antara 5,56-6,81 mg/l dengan rata-rata $6,29 \pm 0,45 \mathrm{mg} / \mathrm{l}$ dan musim peralihan-I berkisar antara $6,03-7,23 \mathrm{mg} / \mathrm{l}$ dengan rata-rata $6,68 \pm 0,38 \mathrm{mg} / \mathrm{l}$. Nilai ini relatif normal dan sesuai dengan kadar oksigen terlarut di lapisan permukaan laut umumnya. Kadar oksigen di permukaan laut yang normal berkisar antara 5,7$8,5 \mathrm{mg} / \mathrm{l}$ dan kadar oksigen di perairan laut yang tercemar ringan di lapisan permukaan adalah $5 \mathrm{mg} / \mathrm{l}$ (Sutamihardja, 1978). Nilai oksigen terlarut masih dalam ambang batas untuk kehidupan biota laut adalah $\geq 5 \mathrm{mg} / \mathrm{l}$ (Kepmen LH No 51 Tahun 2004). Kadar oksigen terlarut di perairan ini relatif belum tercemar oleh senyawa-senyawa organis dan masih baik untuk kehidupan biota laut.

Kosentrasi oksigen terlarut menunjukkan nilai terendah penyebarannya menuju ke arah darat dan sebaliknya ke arah tengah teluk konsentrasinya makin tinggi (Gambar 4). Rendahnya kadar oksigen terlarut pada musim barat di perairan ini disebabkan karena keberadaan sampah dan limbah juga cukup banyak yang pada gilirannya banyak membutuhkan oksigen untuk penguraiannya. Kadar oksigen terlarut dalam suatu perairan akan menurun akibat proses pembusukkan bahan organik, respirasi, dan reaerasi terhambat (Klein dalam Andriani,1999). Menurut Reid, 1961; Welch, 1980 dalam Simanjuntak (2007) kadar oksigen dalam suatu perairan sangat dipengaruhi oleh meningkatnya bahan-bahan organik yang masuk ke perairan disamping faktor-faktor lainnya diantaranya kenaikan suhu, salinitas, respirasi, adanya lapisan di atas permukaan air, senyawa yang mudah teroksidasi dan tekanan atmosfir.

\subsubsection{Fosfat}

Fosfat merupakan zat hara yang penting bagi pertumbuhan dan perkembangan hidup organisme di laut terutama fitoplankton. Namun bila zat ini kosentrasinya sangat besar di perairan dan melebihi nilai ambang batas maka terjadinya blooming fitoplankton yang menyebabkan kematian berbagai jenis biota laut. Hasil pengukuran menunjukkan bahwa kadar fosfat masih dalam batas aman bagi kehidupan biota laut. Kepmen LH No 51 Tahun 2004 menetapkan standar baku mutu senyawa fosfat untuk biota laut sebesar 0,015 mg/l. Ketchum (1969) menetapkan suatu nilai fosfat sebesar 0,087 mg/l sebagai batas atas pada air yang tidak tercemar. Kadar fosfat pada musim barat berkisar antara 0,0039-0,0214 mg/l dengan rata-rata $0,0088 \pm 0,0056 \mathrm{mg} / \mathrm{l}$ dan musim peralihan-I berkisar antara 0,0024-0,0099 $\mathrm{mg} / \mathrm{l}$ dengan rata-rata $0,0044 \pm 0,0021 \mathrm{mg} / \mathrm{l}$.

Kosentrasi fosfat tertinggi ditemukan di stasiun 3 dan 6 (Gambar 5), menigkatnya kadar fosfat diduga diakibatkan pengaruh musim, pada musim barat terjadi tiupan angin barat yang sangat kuat disertai gelombang dan arus sehingga menyebabkan proses pengadukan (turbulence) yang akan memperbesar kadar fosfat. Sedangkan rendahnya kadar fosfat diduga disebabkan kurangnya pasokan zat-zat organik dari daratan menyebar yang mengandung zat hara fosfat dan mungkin dapat pula disebabkan oleh aktifitas fitoplankton yang intensif. Kadar fosfat yang diperoleh di perairan ini masih subur, menurut Ilahude et al., (1975) kadar fosfat di lapisan permukaan laut yang subur di dunia mendekati $0,019 \mathrm{mg} / \mathrm{l}$. Informasi tingkat kesuburan perairan ditinjau dari kandungan zat hara di perairan pantai belum diperoleh angka yang baku karena dipengaruhi kondisi perairan dan bervariasi dalam dimensi ruang dan waktu (Anonimous, 1985). 

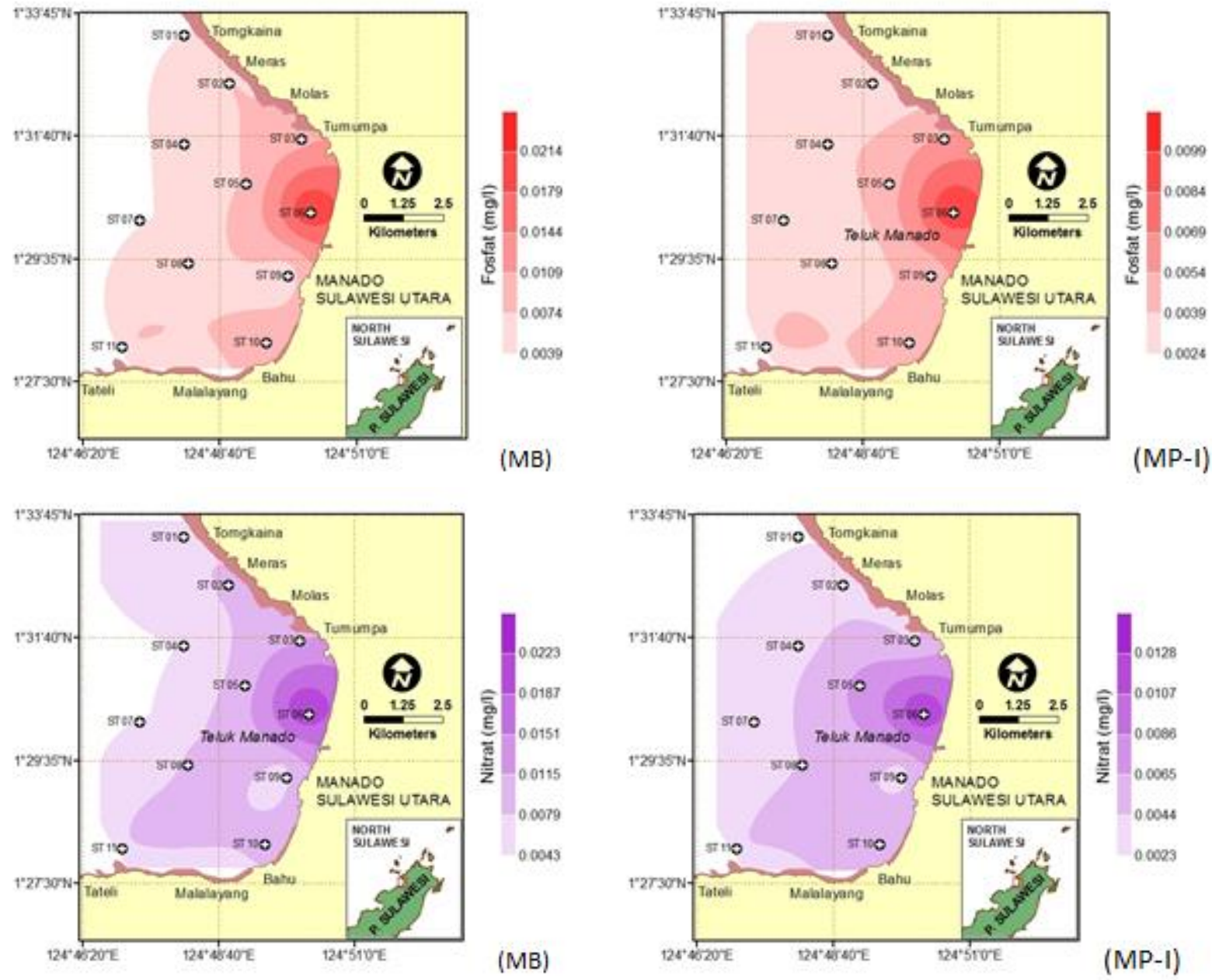

Gambar 5. Sebaran fosfat dan nitrat pada musim barat (MB) dan musim peralihan-I (MP-I) di perairan Teluk Manado.

\subsubsection{Nitrat}

Seperti halnya zat hara fosfat, nitrat juga merupakan salah satu nutrisi yang dibutuhkan mahluk hidup dalam perairan. Kadar nitrat tertinggi diperoleh pada musim barat berkisar antara 0,0043-0,0223 mg/l dengan rata-rata 0,091 $\pm 0,0048 \mathrm{mg} / \mathrm{l}$ dan terendah pada musim peralihan-I berkisar antara 0,0023-0,0128 mg/l dengan rata-rata 0,0052 $\pm 0,0028 \mathrm{mg} / \mathrm{l}$. Tingginya kadar nitrat di musim barat diduga disebabkan banyaknya pasokan sedimen yang mengandung nitrat dari daratan menuju ke laut pada saat hujan. Sedangkan rendahnya kadar nitrat pada musim peralihan-I lebih cenderung dipengaruhi oleh arus dan proses pengadukan (turbulensi) masaa air laut yang mengandung nitrat rendah.

Kosentrasi nitrat tertinggi dijumpai pada stasiun-stasiun yang dekat dengan muara sungai (Gambar 5). Dari gambar tersebut terlihat jelas kosentarasi nitrat tertinggi penyebarannya ke arah darat sebaliknya ke arah laut nilai nitratnya rendah. Kondisi ini mungkin disebabkan banyaknya pasokan zat-zat organik yang mengandung zat hara nitrat masuk ke perairan pantai terbawa oleh arus. Kisaran kadar nitrat di perairan ini masih layak untuk kehidupan biota laut yaitu 0,008 mg/l (Kepmen LH No 51 Tahun 2004) dan dalam batas aman kesuburan suatu perairan. Effendi dalam Simanjuntak, 2012 menyatakan kadar nitrat perairan $>0,2 \mathrm{mg} / \mathrm{l}$ dapat mengakibatkan terjadinya eutrofikasi yang dapat merangsang pertumbuhan fitoplankton dengan cepat (blooming). 


\subsection{Indeks Pencemaran}

Status mutu kualitas air dapat dilihat dari nilai indeks pencemaran. Hasil perhitungan menunjukkan bahwa status mutu perairan Teluk Manado tergolong kondisi baik hingga tercemar ringan, dengan indeks pencemaran 0,34-2,33 (Tabel 2). Nilai indeks ini masih rendah bila dibandingkan dengan hasil penelitian yang dilakukan oleh Suharto dkk., 2018 yang melakukan penghitungan nilai indeks pencemaran dengan metode yang sama pada wilayah pesisir Kota Makasar yaitu 1,29-3,23; parameter yang berkontribusi di setiap stasiun adalah fosfat dan nitrat.

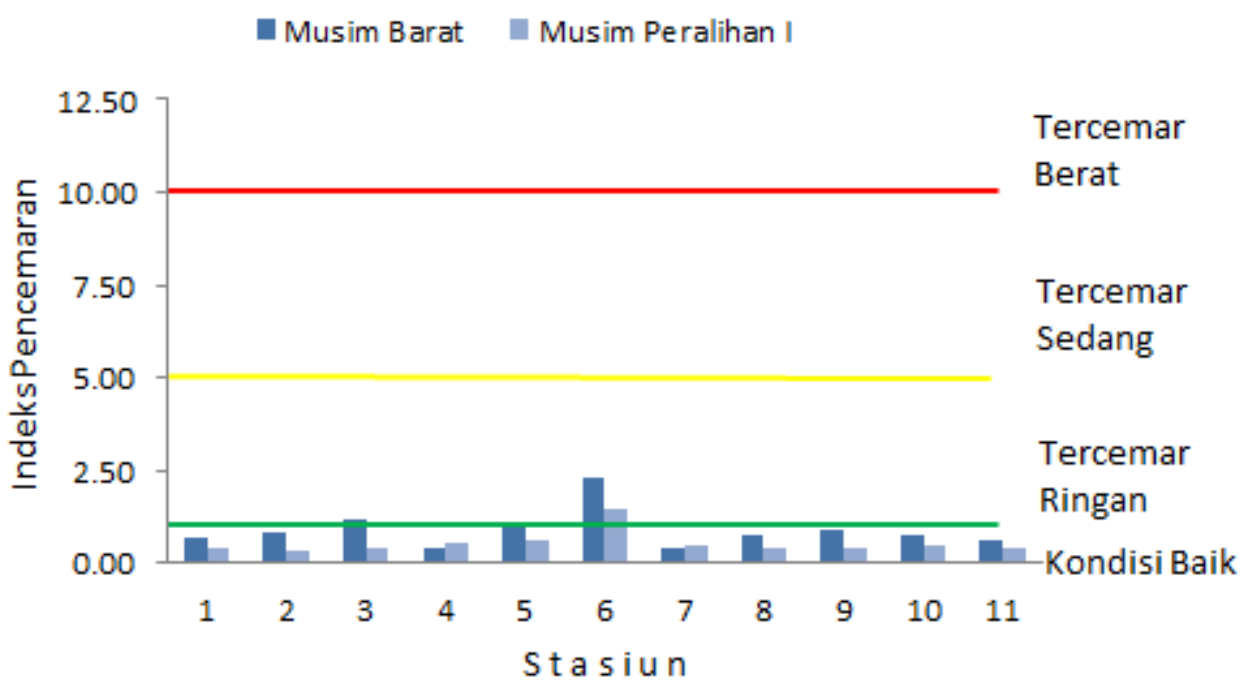

Gambar 6. Indeks pencemaran di perairan Teluk Manado.

Dari Gambar 6, terlihat stasiun 3, 5 dan 6 sudah dalam keadaan tercemar ringan. Tingkat pencemaran tertinggi ditemukan di stasiun 6 yaitu pada musim barat dengan nilai indeks pencemar 2,33 dan musim peralihan-I dengan nilai indeks pencemar 1,44. Tingginya tingkat pencemaran disebabkan lokasi pengambilan sampel berdekatan dengan pelabuhan, kawasan industri, pemukiman dan sungai yang menjadi penyumbang limbah pada perairan laut. Parameter lingkungan yang memiliki konsentrasi tertinggi melampaui baku mutu air laut adalah fosfat dan nitrat. Hal ini perlu menjadi perhatian mengingat kedua parameter tersebut mengandung zat hara dan nutrien, dimana jika berada dalam konsentrasi tertentu akan menyebabkan terjadinya eutrofikasi (blooming) yang berbahaya bagi kelangsungan hidup biota (Hamuna $d k k$. 2018).

\section{Kesimpulan}

Kualitas perairan Teluk Manado dipengaruhi oleh musim. Perubahan yang terjadi terhadap beberapa parameter fisik dan kimia perairan relatif tidak mencolok dan masih dalam batas aman untuk kehidupan biota laut. Hasil perhitungan indeks pencemaran menunjukkan Teluk Manado masih dalam kondisi baik hingga tercemar ringan. Parameter lingkungan yang menjadi kontribusi terhadap status mutu air adalah zat hara fosfat dan nitrat. 


\section{Daftar Pustaka}

Andriani, E. D., 1999. Kondisi Fisika-Kimiawi Air Perairan Pantai Sekitar Tambak Balai Budidaya Air Payau (BBAP) Jepara, Kabupaten Jepara, Jawa Tengah. Skripsi. Fakultas Perikanan dan Ilmu Kelautan, Institut Pertanian Bogor.

Anonim 1985. Laporan Tahunan Sub Proyek Penelitian Sifat-sifat Oseanologi Laut Dangkal Puslitbang Oseanologi, Jakarta. Periode 1985-1986: 138-154.

APHA, AWWA, WEF, 2005. Standard Method For The Examination Of Water And Wastewater, Edition 21: 4-153.

Bowden, K.F., 1980. Physical Oceanography of Estuaries. Englewood Ltd. 476 pp.

Da'i, C.F., 1991. Reef Environment and Coral Fauna of Southern Taiwan. Atoll Resources Bulletin 354:1

Effendi, H. 2003. Telaah Kualitas Air. Jurusan Managemen Sumberdaya Perairan. Fakultas Perairan dan Ilmu Kelautan. IPB: Bogor.

Hadikusumah dan Sugiarto 2001. Penelitian Sumberdaya Laut di Kawasan Pengelola dan Pengembangan Laut (KAPPEL) Sulawesi Utara. Bidang Oseanografi, Proyek Pengembangan dan Penerapan IPTEK Kelautan. Laporan Akhir. Pusat Penelitian dan Pengembangan Oseanologi. Lembaga llmu Pengetahuan Indonesia: 1-21.

Hamuna, B., Tanjung, R., Suwito, Maury, K., Alianto. 2018. Kajian Kualitas Air Laut dan Indeks Parameter Fisika-Kimia Di Perairan Distrik Depapre, Jayapura. Jurnal Ilmu Lingkungan. Pascasarjana UNDIP. Semarang

Ilahude, A.G., D. P. Praseno, O.H. Arinardi dan A. Nontji, 1975. Peta Oseanografi Hasil Pelayaran Selama Pelita I (1969-1974). Atlas Oseanologi Perairan Indonesia dan sekitarnya. Buku No. 2, LON-LIPI: 1-483.

Banjarnahor, J., 2000. Atlas Ekosistem Pesisir Tanah Grogot, Kalimantan Timur. Puslitbang Oseanologi - LIPI Jakarta, hal. 17.

Kalangi, PNI., Mandagi, A. dan Masengi, KWA., Luasunaung, A., Pangalila, FPT dan Iwata, M., 2013. Sebaran Suhu dan Salinitas di Teluk Manado. Jurnal Perikanan dan Kelautan Tropis. Vol. IX(2): 71-75.

Ketchum, D.H., 1969. Eutrophication of estuaries. In : Eutrophication Causes, Consequences, Corrective National Academy of Sciences, Washington, D.C., : 197-209.

KLH, 2004. Keputusan Menteri Negara Lingkungan Hidup No. 51 Tahun 2004 Tentang Baku Mutu Air Laut Untuk Biota Laut. Jakarta, hal. 32.

Mechta, J., 1989. On estuarine cohesive sediment susvension behavior. Jour. of Geophysical Research. Vol. 94.C10:303-314.

Mulyadi, A. 1999. Pertumbuhan dan Daya Serap Nutrient dari Mikroalgae Dunalilella tertiolecta yang Dipelihara pada Limbah Domestik. Jurnal Natur Indonesia 1I (1): 65 68.

Nemerow, N. L. and Sumitomo, H., 1970. Benefits of Water Quality Enhancement. Report No. 16110 DAJ. prepared for the U.S. Environmental Protection Agency. December 1970. Syracuse University, New York.

Nontji, A., 2002. Laut Nusantara. Penerbit Djambatan. Jakarta: 59-67.

Nybakken, W.J., 1988. Biologi Laut. Suatu Pendekatan Ekologis. Gramedia, Jakarta: 459 hal.

Officer, C.B., 1976. Physical Oseanography of Estuaries and Associated Coastal Waters. John Willey and Sons. New York: $465 \mathrm{pp}$.

Pond and Pickard, 1978. Introductory Dynamical Oceanography. Pergamon Press. Pub. Hedington Hill Hall, Oxford: 486 pp.

Riva'i, R.S. dan Pertagunawan, K., 1983. Biologi Perikanan I, Penerbit CV. Kayago, Jakarta, 143 hal. 
Romimohtarto, K dan Thayib, S.S., 1982. Kondisi Lingkungan dan Laut di Indonesia, LONLIPI, Jakarta: 246 hal.

Salm, R.V., 1984. Coral Reef Management Handbook, Unesco-Rostrea, Jakarta, p. 15.

Salmin. 2005. Oksigen Terlarut (DO) dan Kebutuhan Oksigen Biologi (BOD) Sebagai Salah Satu Indikator Untuk Menentukan Kualitas Perairan. Oseana, Vol.XXX (3): 21-26.

Simanjuntak, M., 2007. Oksigen terlarut dan Apparent Oxygen Utilization di Perairan Teluk Klabat, Pulau Bangka. Jour. Mar. Sci. Ilmu Kelautan. Univ. Diponegoro 12(2):59-66

Simanjuntak, M., 2012. Kualitas Air Laut Ditinjau Dari Aspek Zat Hara, Oksigen Terlarut dan $\mathrm{pH}$ di Perairan Banggai, Sulawesi Tengah. Jurnal Ilmu dan Teknologi Kelautan Tropis, Vol. 4, No. 2, FPIK-IPB. Hal. 290-303.

Suharto, Septiyawati, F. dan D. Yanuarita SB., 2018. Kajian Kualitas Air dan Indeks Pencemaran Wilayah Pesisir Kota Makasar. Jurnal Pengelolaan Perairan. Vol. $1(2): 41-55$.

Susana, T. 2005. Kualitas Zat Hara Perairan Teluk Lada, Banten. Oseanologi dan Limnologi di Indonesia: 59 - 67.

Sutamiharja, R.T.M., 1987. Kualitas dan Pencemaran Lingkungan. Fakultas Pascasarjana, Institut Pertanian Bogor: 92 hal.

Tarigan, M.S. dan Edward, 2000. Perubahan Musiman Suhu, Salinitas, Oksigen Terlarut, Fosfat dan Nitrat di Perairan Teluk Ambon. Pesisir dan Pantai Indonesia IV. Puslitbang Oseanologi-LIPI, Jakarta: hal. 77.

US Environmental Protection Agency (U.S. EPA, 1973). Water Quality Criteria 1972, EPAR3-73-033-March 1973. p.177

Wilson, P.C., 2010. Water Quality Notes: Water Clarity (Turbidity, Suspended Solids, and Color). Department of Soil and Water Science. University of Florida. 